\title{
Philosophical Conceptions of Cultural Space in Russia and Japan: Comparing Nishida Kitaro and Semën Frank
}

\author{
Thorsten Botz-Bornstein* \\ Gulf University for Science and Technology, \\ PO Box 7207, 32093 Hawally, Kuwait
}

Received 24.07.2013, received in revised form 31.07.2013, accepted 04.08.2013

Jean-Luc Nancy notes that the community, since it is no absolute subject (self, will, spirit), is by its nature not inscribed in any logic metaphysics. In spite of this, or indeed because of this, Western philosophy has persistently tried to interpret the community through precisely these metaphysical terms (Nancy, 1986, page 18, La Commonauté désoevrée, Christian Bourgeois, Paris). Some thoughts about Russian and Japanese notions of community and space will show that characteristics pointed out by Nancy and Kant are binding only for societies that function within a Western intellectual framework. I want to introduce and compare the thought of Nishida Kitaro. (1870 - 1945) and Semën L Frank (1877 - 1950), who develop the notions of basho and sobornost' as alternative philosophical concepts of space. Both Nishida and Frank attempt to overcome what they consider a typically 'Western' idea of individual 'I's as materialized 'objects'. Procedures like Einfü h-lung or intuition are inefficient because all they do is to transform the other, from the point of view of the 'I', into an object. Finally, for the Eurasianist, the state organization had at its center a personal god, and the 'symphonic personality' of Russia-Eurasia represented a nonegoistic, communal consciousness.

Keywods: Nishida Kitaro, Semyen Frank, Basho, sobornost', philosophy of space, comparative Russian and Japanese philosophy.

\section{Introduction}

In the 1960s, Hugh Seton-Watson explained to all reformers of Africa and Asia that what is "more beneficial to them than the ritual invocation of Asianism or négritude" is the "the study of Russian and Japanese experience [of reform]." As a matter of fact, Russia and Japan are not only successful reformers but also the first "non-western" countries that develop a philosophy - in the "western" sense - of their own and on a larger scale. Still it seems that, in spite of this striking parallel, no comparative research has been done on these two philosophical traditions.

In general, both Japanese and Russian philosophies are engaged in the analysis of the relationship between faith and reason as well as in the critique of secularism. Concepts like "organicity," "person," and "totality" are central in both traditions and among the most popular philosophical themes discussed are reflections on the problem of personalism and philosophical developments of "intuition." Still, while studies on "Nishida and Heidegger" are numerous,

(C) Siberian Federal University. All rights reserved

* Corresponding author E-mail address: thorstenbotz@hotmail.com 
topics like, say, "Nishida and Berdiaev" or "Watsuji and Trubetzkoy" have never been taken up for examination. The objective of the present article is to sketch the cultural similarities between Japanese and Russian conceptions of space through an examination of the Japanese notion of basho and the Russian notion of sobornost'. In particular, I will undertake a comparative analysis of the thought of the most important Japanese philosopher of the twentieth century, NISHIDA Kitarō (18701945), and Semën L. Frank (1877-1950) whom the historian of Russian philosophy Zenkovsky has put forward as "Russia's greatest Twentieth Century philosopher" (Zenkovsky 1995, 872). A comparison of both philosophers is appropriate because both engage in a modern philosophy of religion that maintains a critical distance with concepts of Western European Christianity. The originally Jewish Frank concentrates on Russian orthodox belief (to which he converted) and Nishida derives much of his most important insights from Zen-Buddhism.

For many intellectuals it has become almost obligatory to declare the commitment to any kind of collective - be it a nation, a caste, or an ethnicity - to be false because it oppresses those that are inside the community as much as those on the outside (Cf. Nussbaum 1996) Also, communitarianism is said to run the risk of creating an unacceptable relativism. I think that Russian and Japanese concepts of space and community that will be presented become interesting precisely here because, paradoxically, their reflections of community carry implicit statements about the international order by which these communities are defined. This does not mean that organic communities are extended over continents. At stake is a much more sophisticated idea that also finds an echo in some of those thoughts that have most recently entered our contemporary agenda. Homi K. Bhabha writes in
The Location of Culture that at present through "the emergence of the interstices - the overlap and displacement of domains of difference $-[\ldots]$ the intersubjective and collective experience of nationness, community interest, or cultural value are negotiated" (Bhabha 1994, 2). For Bhabha, the most interesting contemporary questions about "communities" are those that ask how "subjects [are] formed 'in-between,' or in excess of the sum of the 'parts' of difference..." (ibid.).

An "in-between" or "excess" produced through multicultural mixture as much as through our eminent prismatic reading of the world asks for a redefinition not only of homogenous national cultures but also for a reformulation of the notion of the community itself. And this also concerns the "supra-national community." It is important to rethink the community by avoiding not only the "egocentric" essentialism but also the cooperative one.

Sobornost' is commonly associated with the Slavophile A.S. Khomiakov (18041860), but has also been elaborated by Sergei Bulgakov (1871-1944) and Nicolai Berdiaev (1874-1948). The untranslatable term can be rendered into English as "conciliarity" supposed to balance the relationship between authority and freedom. However, sobornost' is more than just a "community" linking several individuals together. ${ }^{2}$ As a dynamic principle, sobornost' does not so much describe the individual's merging with or absorption by collectivity - as would do the obshchina (peasant community) so important for the Slavophiles - but rather an Aufgehen ${ }^{3}$ of the individual in the collectivity. It is Frank who developed this potential of sobornost'.

In a similar way, Nishida's model of basho describes a very specific relationship between the individual and the community. In summary one can say that for Nishida, the "'together' of the most extreme differentatedness" (Weinmayr 2005, 235). is assembled through concepts like 
"discontinuous continuity" or "contradictory selfidentity" - concepts which are definitely not part and parcel of Western analytical equipment. More precisely, basho (as much as Frank's sobornost') eludes at least three Western social models:

1. The Hobbesian rationalist dichotomy between the self and the other because basho and sobornost' do not insist on the forces of alliances but on those of the community as a creative unity.

2. The Kantian model of a "peace federation" (foedus pacificum) developed by Kant in Zum Ewigen Frieden (Goto-Jones 2005, 795) because basho and sobornost' suggest "collective spheres" rather than groupings.

3. Rousseauian theories of the social contract by putting forward a paradoxical form of self-actualization that leads towards greater unity.

\section{Sobornost'}

Sobornost' already existed in the Old Russian tradition and is probably the most "original" concept of community that Russians can think of. Its origin is unknown. Sobornost' is a politicoreligious notion that gives priority neither to Being nor to consciousness but sobirat' means simply "to bring together" and sobor means "council." The apostles of the Macedonians, S. S. Cyril and Methodius, are believed to have tried to render the meaning of the Greek katholikos (universal) through the Macedonian Slavic sobornajai (Christoff: 146). Though Berdiaev affirms that in traditional orthodox doctrine one would find sobornost' with difficulty (Berdiaev 1925), sobornost' is certainly representative of Old Slav Russian democracy present in the village community called the mir (Masaryk, 1955, 14). While in Russian literature allusions to sobornost' are rare before 1848 (Christoff: 139), the notion appears relatively frequently in the latter half of the $19^{\text {th }}$ century as a philosophical tool helping to metaphysically underpin political, social, economic, and aesthetic positions that are believed to be particular to Russian culture. It has been reevaluated, especially by Khomiakov who described it as a "mystical unity of god and man" (Christoff: 126). After the First Slavic Congress in 1867, religious connotations of the sobornost' receded into the background. Through its rootedness in certain Russian social conditions, sobornost' could become a subject of sociological analysis. As a church of ecumenical councils it could be opposed to a monarchical ecclesiology. ${ }^{4}$ As a social principle of the Russian peasant commune and the family (Riasanovsky 1972, 9) providing a vision of integration, peace, and harmony, it could be opposed to authoritarianism and to individualism. As the expression of a purified social consciousness it could be opposed to the European (that is "Roman") political consciousness (Christoff: 173) that has always been over-dependent on juridical, administrative and private laws.

Many of the politico-social reflections on sobornost' have been justified through substantialist ideas about the cultural difference of "the Slavic race" defined in opposition to the "Germanic race" with its entrenched penchant for limiting personal freedom by means of authority (while Germanic peoples need laws, Slavs manage "to limit the personal freedom of each member of the society through the moral authority of the unanimous will of all of its members," Paradoxically, while freedom and unanimity were seen as the real essence of Slavic life, in the end, racial, political, and religious conditions of Russia pushed sobornost' towards autarky. In the worst case, however, attempts were made to retrospectively impose religious elements upon certain social versions of sobornost'. Then sobornost' was declared to be a sanctified original peasant commune (obshchina). ${ }^{6}$ 
Vladimir Solov'ëv (1853-1900) rationalized sobornost' until it became a sort of All-Unity. He questioned especially the Slavophiles' simplistic identification of the Orthodox Church with the Russian people (Riasanovsky 1955, 193). His critical adoption of this concept goes in the direction of a philosophical anthropology that contradicts any egoistic self-enclosure of man (Berdiaev 1948, 50). When Hegelian language was used, moments of rationalization became even more obvious. Here sobornost' could be openly translated as All-Unity (as has been done, for example, by Ivan Il'in) (Christoff 152). True, already in the Orthodox Church sobornost' represented an "organic synthesis of multiplicity and unity" (Riasanovsky 1952, 162). The difference is that the orthodox tradition claimed sobornost' as a spiritual unity of supra-personal and atemporal nature that comes closer to a religio-aesthetic consciousness than to a political unity.

\section{Space in Russia and Japan}

Sobornost'becomesinterestingagainthrough the thoughts of the "Silver Age" philosopher Semën L. Frank. ${ }^{8}$ In Frank's philosophy sobornost' loses all of its autochthonous character of mir or peasant commune. The Japanese equivalent of mir is mura, both of which are traditional status societies and corporate entities that "distinguish between insiders and outsiders." Frank's sobornost' is as far removed from the sobornost'। mir definition as Nishida's basho is from the mura.

Frank, who is often associated with Bulgakov and Berdiaev, was immensely fascinated by the works of the Slavophiles and Solo'viëv's “Total Unity." However, in spite of this rootedness in the orthodox tradition, Frank, who was exiled in 1922 at the age of thirty-seven, produced a "modern" philosophy with a clearly European flavor. Frank's main focus is on the relationships between philosophy and psychology as well as on possibilities to bridge the gulf between thought and being. His biographer Philip Boobbyer writes that Frank's "purpose was to redefine freedom in a conservative context (Boobbyer 1995, 146)." This purpose could also be attributed to Nishida. Another point that both have in common is that Nishida and Frank, who are only separated by seven years of age, engage in a sort of Bergsonian rationalist anti-rationalism which leads them towards conceptual redefinitions - or rather philosophical overcomings - of the idea of space and community in their respective traditions.

Much of what has been written on sobornost' before Frank is reminiscent of the thoughts of the Japanese communitarians and agrarians who opposed the social structure of custom to law and which $\mathrm{H}$. Harootunian resumed like this: “Japanese 'native ethnology' upheld an image of the collective body that spoke, moved, and acted habitually, with necessary conscious intent (...) internalized reflex." ${ }^{.10}$ In other words, the communal body was believed to function like an automatic organism in which knowledge was part of an idyllic environment. ${ }^{11}$

Another Japanese traditional concept of communitarian space that Nishidahad to overcome Nishida was kokutai. The above description of sobornost' might have led a careful reader to a perception of parallels between this traditional Russian notion and the Japanese theory of national polity, kokutai. Kokutai has been Japan's main national ideology dominant during all its modernization period up to the end of WWII. Between 1930 and 1945 kokutai has been strongly associated with nationalism and thought control ${ }^{12}$ and can therefore be compared on the Russian side not only with the idea of "Holy Russia" or Russian imperial theories of the "Third Rome,"13 but also with the traditional notion of sobornost' as an organic-religious collectivism that has for so long been intrinsic in Russian culture and has also 
repeatedly been exploited by authorities (Epstein 1995, 281). However, the fundamental difference between the use that Nishida makes of kokutai in his 1944 article "On the National Polity" and the conception developed by orthodox nationalist during World War II, is that Nishida focuses on kokutai's philosophical, religious, cultural character that, by its nature, cannot be grasped with the help of concrete, materialist notions (Cf. Botz-Bornstein 2003, 127).

\section{Basho}

The idea of basho came to Nishida when analyzing the notion of chora as it occurs in Plato's Timaeus. Appearing as diametrically opposed to the Aristotelian substance (ousia), basho represents a new ontological category summarizing Nishida's personal, Japanese version of the Western intuition. The notion appears first in the collection of essays From the Acting to the Seeing (Nishida 1927, 6). Though literally, basho means "place," Nishida's basho is rather a "negative space" in which things do not simply "exist" but in which they are "local", i.e. in which they "are" in a concrete way. This makes of basho an existential place in which the objective world establishes itself.

In his later work, Nishida sees basho also as a "place" of "history forming." The "place" forms an historical world that is not biological or material, but cultural, and science can only "objectify" this world by discovering intellectual objects, i.e. by reducing the world to noemata. In basho such an objectivation takes never place because here the world is seen the selfdetermination of a socio-historical world, which always maintains an individual-general aspect. In a way, local culture "transcends itself."

This is one of the reasons why this space is cultural or "spiritual." Through the philosophy of basho as a non-objectified space, "spirit" receives a sense of openness that makes it incompatible with models of totalitarian enclosure. When Nishida says that the "real state must be religious at its roots" (Nishida 1944, Engl. trans. 19) he has in mind the religious value of culture determined by the particular Buddhist idea of "self as nothingness." In Fundamental Principles of a New World Order he writes: "Only when every state and every people develops itself and at the same time transcends itself in order to create a world of worlds, every single culture creates, following its regional tradition, a special world. The particular worlds that have formed itself on this historical foundation unite so that the whole world represents a worldly world (Nishida 193334, 429)." More interestingly, also intercultural space is here created through "self-negation" (cf. Maraldo 1995) a problem that will be examined below along the lines of a comparative analysis of Nishida and Frank. Before doing this, however, it will be necessary to reflect these Russian and Japanese ideas against some of the most conventional Western ideas of space and community.

\section{Space and Community}

Jean-Luc Nancy has recently reminded us of the most generalized Western consciousness that is "always subject to the nostalgia of an ever more archaic and more lost community, mourning lost familiarity, fraternity and conviviality." ${ }^{14}$ Nancy's observation is especially true in the sense that this nostalgia longs primarily for "emotional" elements like familiarity and fraternity. It rarely yearns for the lost capacity of mutual scientific understanding, "lost democracy," or common forms of reasoning.

What comes first to mind when hearing of emotional ties that bind together individuals are not only Emile Durkheim's or Talcot Parson's social theories about the collective consciousness $^{15}$ but also Ferdinand Tönnies's (1855-1936) distinction between community 
(Gemeinschaft) and society (Gesellschaft). In principle, Tönnies theory provides a relatively simple organicist logic (later refined by Tönnies himself) about the formation of states (Tönnies 1886). While in Russia discussions of community and society thrived much earlier (mainly in the literary output of the Slavophiles), references to Tönnies are very frequent in Nishida and his Japanese contemporaries. WATSUJI Tetsurō, MIKI Kiyoshi and RŌYAMA Masamichi had elected a Gemeinschaft-like, typically "Oriental," brand of community called kyōdotai as a main topic for their Shōwa Research Association (See Fletcher 1979, 52). Watsuji defined in his Rinrigaku cultural, existential space as determined by a Gemeinschaft when writing: "As Tönnies has said, family bonds are realized in the home, neighborly unions in the matrices of historical tradition, and in turn they create new historical traditions day by day" (Watsuji 1937, Engl. transl. 276).

Also Nishida uses Tönnies as a reference in his kokutai article when writing: "A historical society that actually exists does not arise in the manner of 'from many to one.' It develops in the form of transition from communal society to profit society. To use Tönnies's word, it arises from an essential will, Wesenswille. And an actual existing society is always comprised of both Gemeinschaft and Gesellschaft dimensions. It begins as a center that is a contradictory identity." For Japan as an emerging agrarian community, Tönnies' organic community could appear as an alternative to modern models of society. A minzoku (community) could be seen as a natural community that had not yet been mediated by the state, unlike the kokumin (society). However, as the latter quotation clearly shows, Nishida does not reinstate Tönnies claim for community but uses Tönnies' contrasting notions in order to emphasize his idea of community as based on a "contradictory self-identity."
Nancy's allusions concord perhaps even more with a conception of the community that Kant suggests in Section 20 of the Critique of Judgment in which Kant defines the "community sense" (Gemeinsinn) as the human ability to judge according to the same "feeling" (Gefühl). ${ }^{16}$ While Kant is here not explicitly speaking of the community in a spiritual-ethical-political sense, the reflection upon the "aesthetic sensibility" of individuals does still lead him to the formulation of something that is "common" to a group of people. The important point is that common sense (sensus communis) communicates common forms of cognition but that the human attitude towards community is not based on reason and understanding. Kant makes clear that the Gemeinsinn - and thus community itself - is a matter of subjectivity that transcends the feeling of the single person in order to become common. In a word, for Kant, community is not a matter of common reasoning but of common judgments about taste and ethical matters. ${ }^{17}$

Though Kant points his finger only on a partial constitutive component of the community, Japanese society represents perhaps by definition the ideal example of a community united through common judgments about taste. Roy Andrew Miller has written that in the 17th century, Japan, "in spite of civil unrest, was still united in what may be thought of as a fixed axis of basic taste" (Miller 1961, no page numbers). The expressed nostalgia did not always suggest replacing modern society with a more archaic community. While society has frequently been seen as a degradation or loss of community, "community" can also signify the loss of society. The advancement of "community" can signify the degradation of the free citizen who enjoys all the privileges a sovereign society can offer.

Nancy notes that the community, since it is no absolute subject (self, will, spirit), is by its nature not inscribed in any logic of metaphysics. 
In spite of this, or indeed because of this, Western philosophy has persistently tried to interpret the community through precisely these metaphysical terms (Nancy, 18). If this is meant to represent a kind of Western "intellectual framework," the Russian and Japanese notions of community and space as defined by Frank and Nishida definitely represent alternatives.

\section{Basho and Sobornost': NISHIDA Kitarō and Semën Frank}

Much earlier than Tönnies, in $19^{\text {th }}$ century Russia, the Slavophiles ${ }^{18}$ accused rationalistic models of social organization based on Roman law of corroding the community (Kireevsky) and of undermining organic social totalities. Though Tönnies belongs to the next generation of social thinkers, his organic understanding of the community that cannot be grasped by rationalism comes very close to that of the Slavophiles. ${ }^{19}$ The "supplement" the Slavophiles provide is that they present society as a derivative of the Roman "state" and see "community" as an allunifying totality. Tönnies' themes, enriched by Slavophile-like anti-Western (anti-Roman/antiAmerican) motives, recur in Japanese discussions of the early $20^{\text {th }}$ century. ${ }^{20}$ The remarkable fact is that Nishida as well as Frank steer around these undertakings.

In general it can be said that when Nishida and Frank talk about basho or sobornost' they produce an intercultural philosophy from a paradoxical standpoint that is "metaphysical yet empiricist [and] that maintain[s] ties to God without departing from the actual world of fact" (Nishitani on Nishida). ${ }^{21}$ Also, they produce a philosophy within which, according to Karsavin's formula, "the West provides the empirical components and the East provides the Absolute." 22 Nishida's focus on "emptiness" as a component of Japanese culture leads not to reflections on "the spiritual" as something abstract but to the consideration of "empty space." What appears strange to a "Western" mind is not as unusual in the Russian tradition. The Slavophiles disagreed with the Roman Catholic and Protestant Church because they insisted that the spiritual content of religion cannot be found in the form of "pure spirituality" but takes place in rituals. In other words, the spiritual is supposed to be played within space in order to be a subject of interest for theology.

Let us start with Frank. One of the thoughts that are dominant in all of Frank's philosophy is that God cannot be understood through analysis but that absolute qualities like God should be approached through relationships. In principle, Frank is a Christian democrat reflecting upon the fallacies of individualism in the modern world and uses sobornost' to define the nature of social being and to crystallize the spiritual nature of society, a project that is both more modern and more sophisticated than a Tönniesian opposition of Gemeinschaft and Gesellschaft. Most generally speaking, sobornost' is for Frank the "invisible," inner, "supratemporal" part of society to which he opposes the visible obshchestvennost (best to be translated into English as "communality" and into German as Gesellschaftlichkeit). ${ }^{23}$

The definition of the 'I' as a social being occupied Frank for decades. Already in 1917, while still in Russia, Frank attempted, in Man's Soul, to define the consciousness of a person, that is "his 'I' as a special reality. This consciousness has, for the most part, the character of a sudden revelation, an unexpected empirical disclosure" (Frank 1917, Engl. transl. 14). Man's Soul abounds with quotations from William James and establishes psychic life as something living and dynamic.

In 1930, eight years after his emigration to Germany, Frank published The Spiritual Foundations of Society, ${ }^{24}$ in which he characterizes sobornost' as 'the primary inner unity, a 
primordial multi-unity, [a] specific form of being" (69). In this book Frank concentrates on the 'I' in the context of the formation of a social "we," which culminates in a description of sobornost as "the indivisible unity of ' $I$ ' and 'thou,' growing out of the primordial unity of "we"" (63).

In 1939, in his most mature work, The Unknowable (which translator Boris Jakim has called "possibly the greatest work of Russian philosophy of the Twentieth Century," ix), Frank revisits the theme of the 'I' and the 'thou' and offers even, in a special section of the book, a very systematical treatment of the topic. Though sobornost' is not mentioned in this context, Frank describes the "we" as a collective in which the individuality of the 'I' is conserved: "The being of 'we' overcomes, even if it also conserves, (in the dual, Hegelian sense of aufheben), the very opposition between 'I am' and 'thou art,' the opposition between 'I' and 'thou"' (149).

In Spiritual Foundations Frank lays the ground for these thoughts by concretely linking them to sobornost'. Frank holds that the nature of social being "can be adequately expressed neither in purely 'subjective' categories nor in purely 'objective' categories. Social being in its nature transcends not only the 'material-psychic' antithesis but also the 'subjective-objective' antithesis. It is subjective and objective at the same time (...)" (79). It is in this sense that sobornost' becomes for Frank an important term when it comes to the definition of social being. The primordial multi-unity of sobornost' should not be mistaken for a sociological model of interaction (72). ${ }^{25}$ Being itself is a concrete totalunity whose essence can be grasped by neither naturalism nor idealism nor positivism (100). In the same way also social being (the 'we') is more than only a subjective synthesis, that is, more than a derivative unification of many 'I's.' Frank expresses deep resentments towards organic theories of social life whose "naturalism" shares all the inconsistencies of naturalism in general (43). For Frank, "paths in forests and fields do not arise because many individuals have agreed to make them, but because individuals separately one after the other - go into a certain direction (...)" (37).

It is in this context that parallels between Frank's and Nishida's definitions of cultural space become most explicit because the definitions of both Nishida's basho and Frank's sobornost' are linked to parallel treatments of the relationship between the 'I' and the 'Thou.' In his essay “The 'I' and the 'Thou" Nishida declares that "a mere isolated individual is nothing at all" which means that the 'I' exists only through its relationship with the 'Thou.' More precisely, the 'I' exists in order to bring about and to maintain the 'Otherness' of the 'Thou' on the one hand; and in order to grant the 'I' its quality as an 'I' on the other. In this sense 'I' and 'Thou' "flow out of the same environment" and are determined by a "common consciousness" (Nishida 1927, 348). Any cultural environment flows out of such kind of interaction.

Nishida's environment that is constituted by an interrelationship of the ' $\mathrm{I}$ ' and the 'Thou' is not an organic model of social interaction. The reason is that Nishida strongly objects to the idea of a socio-historical world as a fusion of different individual bits of consciousness. For Nishida, the 'I' and the 'Thou' do not simply merge in order to create an environment, a society, or a place. On the contrary: within the environment they create, they remain 'I' and 'Thou' through mutual recognition. Nishida writes about intuitive processes that apparently help to understand the other: "Intuition - of which the model is normally thought to be artistic intuition - does not mean that we are immediately united with things. It is rather that deep down inside us resides the absolute other, so that at the bottom of its self, 
the self has to become the "Other"' (I and Thou, 390).

Also Frank is convinced that "if 'I' and the subject of knowledge coincided in the sense of complete identity, I could never encounter other beings like me" (47).

There must be something like a 'Thou' because...

....another ' $\mathrm{I}$ ' for me is not merely an object that I know and apprehend but also a subject who apprehends me. In communion, another consciousness is for me what is expressed grammatically as 'thou,' the second person pronoun. But what is 'thou' if we analyze it in terms of abstract epistemology? It is also another consciousness which I apprehend as apprehending me (48).

Only through the interaction of the 'I' and the 'Thou' can society, as the experience of the 'we' that it is, create itself. The 'we' is not derivative of the 'I'. Nor is it the sum or aggregate of many 'I's but it is "rather a primordial form of being, correlative to 'I"' (51).

For Frank the unity of 'we' resides in the primordial unity of multiplicity itself. It resides "in the fact that the very multiplicity of individuals can live and act only as the self-revelation of the unity which embraces and pervades this multiplicity" (52). The unity of society exists "as the consciousness of communality that is as the idea of 'we' in its individual members" (45). Should these individual members really fuse into an organic community, this consciousness of communality would cease to exist. "Knowledge of another 'I' and a living meeting with this other 'I' are possible only because 'I' primordially seeks this meeting" (49).

Frank perceives a mirroring effect of the 'I' and the 'Thou' when he states that "even as two mirrors facing each other give an infinite number of reflections, so the meeting of two consciousnesses - understood as mutual external apprehension - presupposes an infinite number of such apprehension" (48). Also for Nishida the 'I' and the 'Thou' determine each other even before any reflection takes place: "I' and the 'Other' do not become one here, but I am asked to see in myself the absolute other. This might be an unthinkable contradiction" (Nishida 1932: 390). Frank declares that '“I' ideally has a relation to 'thou' before any external meeting with a separate 'thou.' This ideal relation to 'thou,' constitutes the very essence of 'I'" (49). Nishida holds that the contact between 'I' and 'Thou' creates a "self-consciousness" that is based on social consciousness instead of on simple perception. This means that the "place" created by the relationship between the 'I' and the Other represents a kind of "play of reflection" in which the 'I' and the 'Thou' are not opposed to each other.

Both Nishida and Frank attempt to overcome what they consider a typically "Western" idea of individual 'I's as materialized "objects." Procedures like Einfühlung or intuition are inefficient (Frank, 48) because all they do is to transform the other, from the point of view of the 'I', into an object. ${ }^{26}$ Nishida writes:

Even if we adopt an intuitive point of view that will be thought as the unity of subject and object, consciousness will not be detached from the general-conceptual; on the contrary, we attain thus the utmost of the generalconceptual. [...] If intuition means nothing more than that there is neither subject nor object, it is no more than an object. As soon as one talks about intuition, one has already distinguished the knower and the known and again reunited both (Nishida 1926: 222).

Frank concludes along the same lines: If even 'he,' i.e., another consciousness as a pure object, turns out to be an impossible category for the point of view for which the world breaks down in 'I' and 'not-I,' then 
how much more impossible or unexplainable must be for this point of view the concept of 'thou,' the concept of the member of living communion who stands opposite to me (49).

Once these objectified entities have been established, they can be fused into organic communities. Another way to say this is to suggest that Western sociology has scheduled "social being as belonging to the domain of psychic life" (Frank, 71). ${ }^{27}$ Through Descartes' cogito, Western philosophy became able to view the 'we' as a similarly individual quantity as the 'I': "Starting with Descartes, modern WesternEuropean philosophy views 'I' as the bearer of personal, individual consciousness, which cannot be compared with anything else and embraces everything else" (Frank, 46). Against this materializing tendency Frank holds that "social life is not material but spiritual" (71). There is neither cogito nor knower but only "selfconsciousness." This last thought represents for Frank the ideal definition of sobornost'.

Also for Nishida the 'I' does not represent a firm subjective basis into which, within the process of understanding, the 'Other' can be integrated through assimilation. Since the "fusion" of 'I's into a community is not an empirical fusion in the sense of empathy or abstract scientific theories, Nishida's decides to avoid such a fusion by opposing to the cogito the idea that "I know you because you answer me, and you know me because I answer you" (Nishida 1932: 392). Both Nishida and Frank are convinced that man lives in society not because many individuals have joined together. Something in man's essence determines him to be a member of society. Sobornost' is constituted by, and at same time constitutive of individuals. It is concretely individual without being a subject of consciousness separate from society. Nishida expresses the same paradox by saying that society develops itself out of itself as a center that is a contradictory identity.
In both philosophies the notion of "place" is supposed to explain what eludes scientific definition. Nishida's basho is not a Hegelian organic whole (a community or a nation) but a "self-determinating world" which cannot be examined from a scientific point of view because science views society and history as intellectual objects. Basho creates its own structure from the inside and thus represents an "infinite unity" in the sense of unformed matter that is still full of potentialities. For Nishida, the peak of philosophical achievement is neither the definition of the state as a moral substance, nor that of the community as a cultural substance, but the religio-aesthetic definition of a place as the perfect unity of opposites.

In an almost identical way Frank puts the act of differentiation at the center of the formation of the 'I' and the Thou:' "'I' itself is first constituted by the act of differentiation, which transforms a certain fused primordial spiritual unity into the correlative connection of 'I' and 'thou.' But what is this primordial unity? It is nothing else but the principle that is grammatically expressed in the word 'we' (Frank, 49)." The being called 'we' is supported by no original nuclear element called 'I' nor by an all-uniting organic structure called 'we.' All there is is difference between 'I' and 'Thou'.

Nishida's approach is more extreme as he uses the idea of "nothingness" as a self-expressive element flowing out of a similar process of differentiation. Certainly, all cultures, époques and states have a definitely individual character; but the place in which they create themselves is not entirely "positive," it is not the expression of fixed - Deleuze would say "biologically determinable" - elements, but it flows out of "nothingness" as a differentiation active between the elements themselves. Emptiness as an absolute absence of form permits the "place" to accommodate contradictions without resolving 
them. In this sense the "place" is an open ended "horizon."

\section{Transversal Contacts between Frank and Nishida}

Some of the reasons for the striking parallels between Nishida and Frank are inscribed on another level of comparative philosophy, a level that needs to be pointed out because the encounter of Nishida and Frank is far from being hypothetical and constructed. Nishida's philosophy has been continued in the area of psychology by the eminent Japanese psychologist Kimura Bin (born 1931) who studied in Germany with Ludwig Binswanger (1881-1966). Like Binswanger, Kimura is deeply dissatisfied with the orientation of psychology towards the natural sciences. It happens that Binswanger was Frank's closest Western-European friend by whom he was supported for years whilst in emigration and in whose house he lived.

Like Frank's, Kimura's psychological writings are lengthy meditations about the status of the "I" as opposed to the empirical self. His idea is to evaluate Nishida's idea of pure experience in the context of psychoanalytic theory, criticizing that for Western schools of psychotherapy psychic experience represents always a verbalizable experience and "even nonverbal phenomena like dreams [and] transfers [...] can be entered into the field of psychotherapy, to the extent that they can be translated into words either by the patient himself or by the therapist" (Kimura 1991, 191, my translation) Verbalization is materialization of psychic experiences. In Western psychoanalysis, Kimura concludes, the patient is obliged to make his consciousness an object in order to construct his psychic life (1991, 200). In the same way, psychology proceeds to the materialization of the 'I'. Kimura insists that the 'I' should be seen as a non-substantial entity that exists only by "reporting itself to itself" (Kimura
1982, 7, my translation) and declares selfperception (jikaku) the original place of human existence: it is through self-perception that man resists all "objectification" of psychic life in order to perceive the Being of things "immediately" (Kimura 1992, 40, my translation).

It is clear that this strategy fully coincides with Frank's thoughts though we have no reason to believe that Frank developed them only under the influence of Binswanger. Already in his preemigration work (Man's Soul) from 1917 Frank writes: "Psychic life is not a mechanical mosaic consisting of psychic stones called sensations, ideas, etc. (...) but a kind of unity (...)" (17-18) and suggests the "delimitation of psychic life from objective being" as an element of experience which leads him to the accentuation of interrelational space. The exclusive existence of the "I" within an "inter-relational" space concords not only with Kimura's Nishidaian ideas but also with Binswanger's for whom this space has been a topic of interest as he writes:

[...] the curious problem that just where you are, "arises" a place (for me). Instead of ceding a position "to the other" within the predetermined spatiality of the ratio and the corresponding loss of my own space, what appears is the curious phenomenon of an "unlimited" increase of one's own space by giving away one's own space! Instead of a predetermined region as such in which the one would dispute "the place" or "the position" to the other, one perceives a curiously undetermined [...] depth [and] breadth in which places and positions no longer exist. ${ }^{28}$

\section{Basho, Sobornost',} and the Eurasianists" "New Globalism"

Through the notion of basho Nishida resolves the aporia of the co-existence of existence and essence. Reflecting all individuals and their mutually determining way-of-being 
within itself, basho is a place in which all living and non-living things come into being, it is a "place" of relational existence in which one perceives the idea of nothingness or emptiness. On the basis of this religious "negativity" introduced into the idea of community, both basho and sobornost' positively engage in reflections on the global world order. Nishida's theory of the basho is opposed to federalism as well as to imperialism but brings forward a new globalism within which each nation is supposed to develop its own culture. This theory avoids ethnic egoism as well as any harmful form of nationalism and comes close to Sergei Bulgakov's concept of a "brotherhood of peoples" (Bulgakov 1986, 44) which Bulgakov preferred to "nationals, atomized 'citizens' or 'proletarians of all countries,."

Nishida's later developments of basho are also reminiscent of the "community of nations" (sobor narodov) of the Eurasianists, ${ }^{29}$ for whom the Aufgehen of the individual in the collectivity had been important. In general, Eurasianist, who formulated perhaps the clearest anti-Western model that has ever existed in Russia, adopted "organic" tones well known since the Slavophiles and Pan-Slavism. They also formulated a critique of Western philosophy as well as reflections on Khomiakov's idea of sobornost' together with impressive degrees of cultural relativism and anticolonialism. ${ }^{30}$ Curiously, these rather conservative thoughts are combined with distinctly progressive ideas about the organization of a multicultural state as laid out by the liberal conservative economist Pëtr Struve (1870-1944), a friend of Frank who was, like Frank, a proponent of political realism. Though Struve certainly entertained a Slavophile "nostalgia for the precapitalist world" (Pipes 1980, 78), his ideas were clearly Western and European.

For the Eurasianist, the state organization had at its center a personal god and the "symphonic personality" of Russia-Eurasia represented a non-egoistic, communal consciousness or, as expressed by Karsavin, a collective personality ("sobornaja lichnost"). For the Eurasianists, any relationship between individual and state is rooted in sobornost'. However, in spite of their conservative and paternalist background, it is possible to see in the Eurasianist writings an "early post-modernist strain" (Girenok) because their idea to identify Eurasia as a localized culture pushes the very opposition East-West towards theories of cultural conversion or transculturalism. Especially the democratic and decentralized "third way" that left-wing Eurasianists like Dimitry Sviatopolk-Mirskii suggested, aims at overcoming Russian nationalism and emphasizes the supra-national character of Eurasianism. ${ }^{31}$ The Eurasianist geographer Savitzky, for example, introduced the idea of the "symposium of people" when writing: "Eurasianists understand Russia as the sobor narodov. They believe that political unity of this vast territory is a result not only of the efforts of just Russian people but of many peoples of Eurasia"32 The sobor narodov can be understood as an "internationalized" version of sobornost'. For the Eurasianists there would be a large quantity of "local patriotisms" sustained by a weak, all-Russian patriotism of the elite. "Eurasian culture" would not simply be the sum of different single cultures but these cultures would "converge" into a symphonic reunion. This is compatible with Nishida's suggestion that a "new world order" can be attained via the typically Japanese idea of "self as nothingness:" just as individual selves exist by mutual selfdetermination and self-negation, so do nations in global place.

The Eurasianist Nicolai Trubetzkoy held that culture migrates, that its centers constantly change in geographical space. Under the influence of the botanist Danilevsky, Savitzky refused to divide the world into clearly defined continents in order 
to avoid "natural classifications" following the natural lines of oceans, mountains, etc. Instead Savitzky suggested the term "geographical worlds" in which characteristics can overlap (Savitzky 1927, 27. See Wiederkehr 2000, 135). The unity of Eurasia, for example, was supposed to be not "natural" but rather based on a model of convergence: "The influence of South, East, and West constantly alternated and consecutively dominated the world of Russian culture" (Savitzky 1925, 8). Cultures are no "undifferential entities" (nedifferenzirovannij sovokupnosti) (ibid, 13): without Tartars there would be no Russia (Savitzky 1922, 123) and Russia itself is a combination of sedentariness and steppe elements (ibid). Unilinear and progressive evolutive systems become impossible: "When the line of evolution extends itself into different branches, there can be neither an ascending movement nor gradual and constant self-accomplishment. This or thatcultural milieu or series [of milieus] is an accomplishment from one point of view but looks like a decline from another point of view" ("Evrasijstvo," 13). Savitzky also introduced the term mestorazvitie (space-development), a theoretical notion through which socio-historical components or even literature and art can be seen as integral parts of geographical conditions. The individual, not unlike the personality, is supposed to appear as a "geographical individual" (Savitzky 1927, 30, 31). Interestingly, the notion of mestorazvitie as a "natural milieu" avoids determinism because there is no "predestination" (see Weidlé 1976, 16). Later, the Eurasianist historian George Vernadsky (1887-1973) gave historical flesh to Savitzky's geographical theories by stressing "the decisive significance of the relation between steppe and the forest societies on the enormous Eurasian plain, the ethnic and cultural complexity of Russia, and the major organic contribution of Eastern peoples, especially the Mongols, to Russian history" (Riasanovsky 1972, 23). Eurasia as a combination of spatial-temporal "undifferential entities" as well as Nishida's vision of Asia as a basho is a "place" that is not shaped by profound, metaphysical structures.

\section{Conclusion}

I have shown in which way certain "nonWestern" concepts of community like sobornost' or basho differ from Kant's idea of "community" as they manage to include - though at the same time fracture - metaphysical items like "self," "will," or "spirit." This shows that the Kantian definition of the community as dependent on nothing other than subjectivity has no absolute value. The "nonWestern" alternatives that have been presented should be considered as a useful addition to our contemporary political discourse. Former Czech president Vaclav Havel explained only recently that "I merely reject the kind of political notions that attempt, in the name of nationality, to suppress other aspects of the human home, other aspects of humanity and human rights. ${ }^{\prime 33}$ The dichotomy of reasoning against feeling, of the rational against the familiar, of the modern against the archaic, persist in our thinking. The Russian and Japanese authors dealt with in the preceding study reject such dichotomies and try to think the community on the basis of principles of convergence in which the relationship between the 'I' and the 'Thou' is no longer inscribed in these schemes.

Further, the reading of the Russian and Japanese authors that has been provided in the presentarticlehelpstoovercomeHuntingtonesque fear of a clash of civilizations. Also Christopher Goto-Jones affirms that Nishida's "alternative model of the inter-civilizational order predates Huntington's 'new world order' by some sixty years" (Goto-Jones 2002, 224). The difference is that Nishida's civilizations manage to avoid the Hobbesian clash because they are not material entities. While it remains true that the world is an unfolding of various types of 
civilization (as Nishida also would affirm), each of these expressions should be recognized as an immediate expression that cannot be subsumed in one single Hegelian idea of "civilization." In other words, every singularity is an expression of the Absolute, and the "harmony" that Frank and the Eurasianists look for when talking about sobornost', is always more than a totalizing Hegelian universalism but comes closer to a Schellingian revelation. ${ }^{34}$ There is no dialectical synthesizing but rather the expression of a general truth.

More important than to theoretically define the limits between different types of Pan-associations (or perhaps pondering about ways to harmonize single cultures by imposing upon them some sort of holistic spirit), is to show ways how these limits can be and - as a matter of fact - constantly are overcome. It is, for example, more important to think about the relationship between the 'I' and the 'Thou,' about the formation of human communities dependent on the contact with the "outer" world (or simply arising through opposition to it), than to define "civilizations" as self-sufficient and egocentric entities.
Contemporary discussions on the "new world order," at the moment they ground their arguments on "cultural" elements, on the other hand, can easily shift towards a Huntington-style cultural essentialism. In Nation and Narration Homi Bhabha argues against this tendency to essentialize Third World countries into a homogenous identity (Bhabha 1990). At the moment a world order is no longer established "artificially," i.e. with the help of valid political ideas, cultural components are called for in order to establish an "organic" order by creating coalitions between cultures in an almost "natural" way. Such ideas accord with historical ideas of Nishida or of Eurasianism only as long as we take a superficial look. The present article was supposed to show that these Japanese and Russian philosophies developed concepts of space through which cultural communities appear as more than merely organic, self-enclosed units. These philosophies constantly confront the contemporary reader with a paradoxical conceptual linking of openness and closedness, of self-awareness and awareness of the other, of reality and transcendence. Like this they manage to overcome both particularism and universalism.

Seton-Watson H, 588. Seton-Watson does not forget pointing out that "no other modernizing state has ever made such a bad job of national education as Imperial Russia, nor such a good job as Japan" (ibid).

2 See Peter K. Christoff, "Khomiakov maintained that they could have used either vsemirnaja or vselenskaja (universal) synodal, cathedral, or even social (public)." 1961, An Introduction to $19^{\text {th }}$ Century Russian Slavophilism. A Study in Ideas, Vol. 1: A.S. Xomiakov (Mouton, S'Gravenhage), page 146.

3 The German philosophical term Aufgehen is translated as "absorbtion" though it differs from the idea of fusion in that it permits the autonomous existence of the merging elements as individualities.

Bulgakov S, pages 74-75, quoted from Christoff, page 173.

5 Hilferding A, 1874, Sobranie sochinenii Vol. IV Istoriia baltiiskikh slavian (St Petersburg), 68-69. Quoted from BoroPetrovich 1956, page 82.

6 The Slavophile Konstantin Aksakov held that obshchina is a peasant commune leading to organic mutuality and social self-abnegation. This is naïve and not plausible as holds also Christoff (Christoff 154).

7 Cf. Victor Bychkov 1998: "Sobornost' signifies the essentially extrapersonal (supra-personal) and a-temporal nature of aesthetic consciousness. This is the consciousness of a community (sobor) of people, akin in spirit, who have reached, in the process of communal liturgical life, a spiritual unity with each other and with the higher spiritual levels, ideally with God..."

8 It remains to mention that as a political term, on the other hand, sobornost' became fashionable up to the point that Dostoevsky could confirm that "the idea of socialism has given way to that of sobornost"' (Christoff, 238). Dostoevsky was disgusted by the French bourgeoisie, which symbolized for him pettiness, false morality, materialism, and selfishness. He contrasts them with sobornost': "The highest use a man can make of his individuality, of the completed development of his I, would be to destroy this I, to return it entirely to all and to each inseparably and supremely. And this is the greatest happiness. In this way the law of I merges with the law of humanity and both are one, and I and all (which appear to be two opposed extremes) are both mutually destroyed, while at the same time they attain the higher goal of their own individual 
development on this basis" (Notebooks entry 16. April 1864 quoted from Lossky's History of Russian Philosophy, 1951, International University Press, New York). Dostoevsky's statement is realistic: Herzen accepted the Russian peasant community as a model for socialism because he found that, contrary to the Asian (Indian) peasant community, the Russian forms of community were more adaptable for modern needs, being less rigid and less patriarchic (Cf. Schelting, 221): "As an organic unity that functions through mutuality and social self-abnegation, the obshchina is certainly to be regarded as the precursor of sobornost" (see Christoff, 154). Herzen even designed a form of "revolutionary Slavophilism" (MacMaster) intended to replace Khomiakov's religiosity with a secular brand of humanism suitable for a rationalist, socialist eighteenth century (cf. MacMaster 181).

9 On mir and mura see Sil R, 2002 Managing "Modernity": Work, Community and Authenticity in Late-Industrializing Japan and Russia (University of Michigan Press, Ann Arbor), 129ff and 197ff. Quotation from page 278.

10 Cf. Harootunian H, 2000, 299-300. Representatives of native ethnology are Gondō Seikei, Tachibana Kōsaburō, Inoue Nisshō, and Nakano Seigō.

11 Today sobornost' is also identified as a kind of precursor of Bolshevik socialism. The neo-Eurasian Igor Panarin identifies 'sobornost' as an aggressive rejection of individual private interests, (...) [which produces] on the whole a lack of initiative, responsibility, independent activity, and high-quality professionalism..." A.S. Panarin, 1992, 61. Panarin's communitarianism, which does not more than idealizing the social whole, does not reflect the sophistication that Frank enclosed to the concept of sobornost'.

12 The kokutai synthesizes Confucian and Shintoist ethical elements and expresses, since late Tokugawa, political contents focusing communitarian issues. Through its partly Shintoist identity, kokutai is tied to the emperor as the patriarch of the national family. Curiously, it was also used in Chinese modernity (as kuo-t'i) by the Hung-hsien reign (See Levenson 1964, 314. The word kokutai comes originally from China where it had another meaning.

13 Constantinople was the Second Rome. Some $16^{\text {th }}$ century Russian writers held that "both Romes" had failed the mission of leading Christianity and required that political and religious supremacy should be granted to Moscow.

14 "Une conscience (...) semble bien accompagner l'occident depuis ses débuts: à chaque moment de son histoire, il s'est déjà livré à la nostalgie d'une communauté plus archaïque, et disparue, à la déploration d'une familiarité, d'une fraternité, d'une convivialité perdues." Jean-Luc Nancy: La Communauté désœvrée (Christian Bourgeois, Paris, 1986), page 31.

15 Durkheim's study of the "lien social" (social link), mainly developed in De la Division du travail social (Paris: Presses universitaires françaises, 1893), asked how people form groups in a more and more individualized society. In traditional societies which showed only minimal differences with regard to production processes, social solidarity was mechanistic and based on geographical proximity, shared histories and values, etc. This communitarian society is replaced by a more organic form of solidarity defined mainly by interdependence. Talcott Parson developed Durkheim's ideas on common sentiments and values for example in The Structure of Social Action (2 vols.), (1937, New York: McGraw Hill, New York), The Social System (1951, Free Press, New York).

16 Kant I, 1908 Kritik der Urteilskraft [Critique of Judgment] (Reimer, Berlin), Section 20, 237-38: "Wenn Geschmacksurteile (gleich den Erkenntnisurteilen) ein bestimmtes objektives Prinzip hätten, so würde der, welcher sie nach dem letzteren fällt, auf unbedingte Nothwendigkeit seines Urteils Anspruch machen. Wären sie ohne alles Princip, wie die des bloßen Sinnengeschmacks, so würde man sich gar keine Nothwendigkeit desselben in die Gedanken kommen lassen. Also müssen sie ein subjectives Prinzip haben, welches nur durch gefühl und nicht durch Begriffe, doch aber allgemeingültig bestimme, was gefalle oder mißfalle. Ein solches Princip aber könnte nur als Gemeinsinn angesehen werden, welcher vom gemeinen Verstande, den man bisweilen auch Gemeinsinn (sensus communis) nennt, wesentlich unterschieden ist: indem letzterer nicht nach Gefühl, sondern jederzeit nach Begriffen, wiewohl gemeiniglich nur als nach dunkel vorgestellten Prinzipien, urtheilt."

17 "Also nur unter der Voraussetzung, daß es einen Gemeinsinn gäbe (...) kann das Geschmacksurteil gefällt werden" (157).

18 'Slavophilism' has two meanings, depending on if it is used in Russia or in Slav countries outside Russia. In Slav countries outside Russia, 'Slavophilism' is a generic term for all pro-Slav movements, including Pan-Slavism. In Russia, Slavophilism is restricted to certain thinkers. I will talk here about Slavophilism in the "Russian" way. The main representatives of the Slavophiles are Ivan Kireevsky (1806-1856), Alexei Khomiakov (1804-1860), Ivan Aksakov (1817-1860), Konstantin Aksakov (1817-1860), and Iurii Samarin (1817-1886). The Slavophiles were a group of Russian intellectuals who defined the values of Russian civilization as independent from Western-European culture. Russian Pan-Slavism adopted certain themes of the Russian Slavophiles though it did not consciously overtake Slavophile ideals. Still, Slavophilism can be seen as the precursor of Pan-Slavism, because it is the first movement coming to terms with questions of Slav cultural identity. The problem is rather that the Russian Slavophiles manifested, in general, no solidarity with the Western Slavs (apart from the period of the Crimean War) and developed their themes into a kind of imperial "Pan-Russianism." This is especially true for the period following the war against Turkey (mid 1870s) where ideologies became racist.

19 Also Tönnies felt that “organic reality" couldn't be grasped by rationalism (Walicki 1975), page 170.

20 Tönnies himself was influenced by conservative German philosophers like Justus Möser and Adam Müller who agitated against French rationalism around 1800 which brings him indeed temporally close to the Slavophiles which shows that the problem of Japan's transformation from a people to a nation reached the Japanese consciousness relatively late (Naoki Sakai even holds that only Maruyama's Studies of Tokugawa Japan brought up this problem). See Epstein K, 1973, Die Ursprünge des Konservatismus in Deutschland (Ullstein, Berlin).

21 Nishitani K, 1991 Nishida Kitarō (University of California Press, Berkley). It is interesting to note that Nishitani held such a standpoint to be "unthinkable in the West."

22 Karsavin L P, 1922 Vostok: Zapad i russkaja ideja (Ogni, Petrograd) quoted from Mehlich, page 108.

${ }^{23}$ See von Schelting A, 221: "The obshchina rested on the principle of obshchinnost (communality)." 
24 Frank 1930. I quote from the English translation. The book's section "I and We," part of the book most discussed in the present article, appeared as a separate article entitled "I and We" in the Collection of Essays in Honor of P.B. Struve (Prague) already in 1926.

25 "In other words, the spiritual unity considered here is not the simple, absolute unity of a subject, but precisely a multiunity, a unity that exists and acts only in harmony and unitedness of many individual consciousnesses" (45).

26 "Another consciousness as a pure object, turns out to be an impossible category for the point of view for which the world breaks down into 'I' and 'non-I,' then how much more impossible or unexplainable must be for this point of view the concept of 'thou,' the concept of the member of living communion who stands opposite me?" (Frank 1987, 49). "This unity of 'we' is not only a unity that opposes multiplicity and separation, but it is also, primarily, the unity of multiplicity itself, the unity of all that is separate and antagonistic, the unity outside of which no human separation and multiplicity are conceivable" (51).

27 Frank 1987, 71 "This is the absolutely insuperable limit to all social materialism, to all attempts at a biological or physical interpretation of social life."

28 Binswanger L, 1953 Grundformen und Erkenntnis des menschlichen Daseins (Niehans, Zürich), page 31, my translation. A more direct contact between Nishida's philosophy and Frank does not seem to have existed. Kimura Bin never met Frank (correspondence with the author).

29 Eurasianism emerged in 1921 and its principal representatives are the linguist Nicolas S. Trubetzkoy, the geographer Pëtr Nikolaevitch Savitzky, the theologian Georgy V. Florovsky and the musicologist Pëtr P. Suvchinsky. A creation of émigré intellectuals, Eurasianists interpret the Revolution of 1917 as the point where Russia left the European world. Their general tendency is to emphasize religious and metaphysical questions, which enables them to establish Russia (like Byzantium) as an amalgam of European and Asian elements, and to see the existence of "Slavic culture" as a myth. For "sobor narodov" see Sergei Glebov: "Science, Culture, and Empire: Eurasianism as a Modern Movement" in Slavic \& East European Information Resources 4(4), page 16.

30 It comes as a poor coincidence that Eurasianism has recently been revalued by the nationalist geopolitician Alexandr Dugin who refounded the Eurasian Movement in 2000. Dugin calls his movement also "radical traditionalism." The conclusions he draws from his "theory of passionarity" are that Russians are a fresh and young ethnos, which has the potential to consolidate the super-ethnos of Russia-Eurasia (cf. Galya Andreyeva Krasteva: "The Criticism towards the West and the Future of Russia-Eurasia" in The Eurasian Politician, July 2003 4.) Eurasianism continues to fascinate theorists. The reason might be that "Eurasia" represents an interesting object for various kinds of people. The American policy-maker Brzezinski claims that even today "Eurasia is [...] the chessboard on which the struggle for global primacy continues to be played.” Zbigniev Brzezinsky. The Grand Chessboard - American Primacy and its Geostrategic Imperatives (New York: Basic Books, 1997), 31.

31 See Torbakov I, 2003 "From the Other Shore: Some Reflections of Russian Émigré Thinkers on Soviet Nationality Policies 1920s-1930s" in Slavic \& East European Information Resources 4(4). Torbakov quotes Mirskii from "National'nosti SSSR" in Evrazija (Paris) 22, 1929 (44).

32 Savitzky P, 1995, 424, quoted from Torbakov page 44.

33 Havel V, 1991, "On Home" in New York Review of Books 5 December. Quoted from Griffin.

34 Schelling's philosophy of revelation ("Philosophie der Offenbarung," a lecture held in 1854) defines philosophy as a science transcending mere rational knowledge. Whatever philosophy creates can be perceived only through experience and revelation. Three forms of revelation of the absolute are: art, religion, and philosophy.

\section{References}

1. Berdiaev N, 1948 The Russian Idea (Macmillian, New York).

2. Berdiaev, N, 1925, "Dukhovnye zadachy emigrazij" Put' 1 .

3. Bhabha H, 1990 Nation and Narration (Routledge \& Kegan Paul, New York).

4. Bhabha H., 1994 The Location of Culture (Routledge, New York).

5. Binswanger L, 1953 Grundformen und Erkenntnis des menschlichen Daseins (Niehans, Zürich).

6. Boobbyer P, 1995 S. L. Frank: Life and Work of a Russian Philosopher 1877-1950 (Ohio University Press, Athens).

7. Botz-Bornstein T, 2003 Place and Dream: Japan and the Virtual (Rodopi, Amsterdam, New York).

8. Botz-Bornstein T, 2004, "The I and the Thou: A Dialogue Between Nishida Kitarō and Mikhail Bakhtin” Japan Review 16.

9. Brzezinsky Z, 1997 The Grand Chessboard - American Primacy and its Geostrategic Imperatives (Basic Books, New York). 
10. Bulgakov S, 1986 "Heroism and Asceticism (Reflections on the Religious Nature of the Russian Intelligentsia)" in M. Shatz and J. Zimmermann (eds), Signposts - vekhi (Schlacks, Irvine).

11. Bulgakov S, 1988 The Orthodox Church (St. Vladimir's Seminar Press, Crestwood).

12. Bychkov V, 1998 "sobornost" Encyclopedia of Aesthetics (Ed. Kelly, Oxford University Press, Oxford).

13. ChristoffK, "Khomiakov maintained that they could have used either vsemirnaja or vselenskaja (universal) synodal, cathedral, or even social (public)." 1961, An Introduction to $19^{\text {th }}$ Century Russian Slavophilism. A Study in Ideas, Vol. 1: A.S. Xomiakov (Mouton, S'Gravenhage).

14. Durkheim E, 1937 The Structure of Social Action (2 vols.), (McGraw Hill, New York).

15. Durkheim E, 1951 The Social System (Free Press, New York).

16. Epstein K, 1973, Die Ursprünge des Konservatismus in Deutschland (Ullstein, Berlin).

17. Epstein M, 1995 After the Future: The Paradoxes of Postmodernism and Contemporary Russian Culture (Massachusetts University Press, Amherst).

18. Flecher M, 1979, "Intellectuals and Fascism in Early Showa Japan" Journal of Asian Studies 39(1).

19. Frank S L, 1917 Dusha cheloveka: opyt vvedenija v filosofskuyu psikhologiyu (republished 1995 by Nauka, Moscow) Engl.: Man's Soul: An Introductory Essay in Philosophical Psychology (1993, Ohio University Press, Athens).

20. Frank S L, 1930 Dukhovnye osnovy obshestvo: vvedeniev sozial'nuyu filosofiyu (YMCA Press, Paris: 1930; republished in New York, 1988). Engl: The Spiritual Foundations of Society: An Introduction to Social Philosophy (1987, Ohio University Press, Athens).

21. Frank S L, 1983, The Unknowable: An Ontological Introduction to the Philosophy of Religion (Athens Ohio University Press) originally published as Nepostizhimoe in Put' May/Sept. 60, 1939.

22. Glebov S, 2003, "Science, Culture, and Empire: Eurasianism as a Modern Movement" in Slavic \& East European Information Resources 4(4).

23. Goto-Jones C, 2002, "If not a Clash then What? Huntington, Nishida Kitarô, and the Politics of Civilizations" International Relations of the Asia Pacific 2, pp. 223-243.

24. Goto-Jones C, 2005 “Transcending Boundaries: Nishida Kitarô, K'ang Yu-Wei, and the Politics of Unity” in Modern Asian Studies 39(4), 793-816.

25. Harootunian H, 2000 Overcome by Modernity: History, Culture, and Community in Interwar Japan (Princeton University Press, Princeton).

26. Havel V, 1991, "On Home" in New York Review of Books 5 December.

27. Hilferding A, 1874, Sobranie sochinenii Vol. IV Istoriia baltiiskikh slavian (St Petersburg), 68-69. Quoted from Boro-Petrovich 1956.

28. Kant I, 1908, Kritik der Urteilskraft [Critique of Judgment] (Reimer, Berlin).

29. Karsavin L P, 1922 Vostok: Zapad i russkaja ideja (Ogni, Petrograd).

30. Kimura B, 1982 Jikan to jiko (Time and I) (Iwanami, Tokyo).

31. Kimura B, 1991, "Signification et limite dans la formation psychothérapeutique" Fedida P and Schotte J (eds) Psychiatrie et existence (Millon, Grenoble).

32. Kimura B, 1992 Ecrits de psychopathologie phénoménologique (Presses Universitaires de France, Paris). 
33. Krasteva G, 2003, "The Criticism towards the West and the Future of Russia-Eurasia" The Eurasian Politician 4.

34. Levenson J, 1964, "The Suggestiveness of Vestiges: Confucianism and Monarchy in the Last" in Wright A (ed.) Confucianism and Chinese Civilization (Stanford University Press, Stanford).

35. MacMaster R, 1967 Danilevsky: A Russian Totalitarian Philosopher (Harvard University Press, Cambridge).

36. Maraldo J, 1995, “The Problem of World Culture: Towards an Appropriation of Nishida's Philosophy of Nation and Culture" Eastern Buddhist 28(2).

37. Masaryk T, 1955 [1919] The Spirit of Russia. Studies in History, Literature, and Philosophy (3 Vols.) (Allen \& Unwin, London).

38. Miller R A, 1961 Japanese Ceramics (Crown, New York).

39. Nancy J-L, 1986 La Communauté désœvrée (Christian Bourgeois, Paris).

40. Nishida K, 1927 From the Acting to the Seeing (hataraku kara mono miru mono e) VOl. I of NKZ 善の研究 (Zen no kenkyū; Study of the good) in NKZ (Nishida Kitarō Zenshū [Complete Works]) (Iwanami, Tokyo, 1965-66).

41. Nishida K, 1932 私と汝 (Watashi to nanji; I and Thou). NKZ 6: 341-427.

42. Nishida K, 1933-34, “Fundamental Principles of a New World Order,” NKZ XII, 429). 哲学 の根本問題 (Tetsugaku no konpon mondai; Fundamental problems of philosophy) in NKZ VII: 3-173. Engl. transl: Fundamental Problems of Philosophy: The World of Action and the Dialectical World. (1970, Sophia University Press, Tokyo).

43. Nishida K, 1944 "Bashoteki ronri to shūkyōteki sekaikan" NKZ XI: 371-464. Engl. transl.: "The Logic of Topos and the Religious Worldview, Part 1" Eastern Buddhist 1986, 19(2), 1-29; "Part 2" Eastern Buddhist 1987, 20(1), 81-119.

44. Nishida, 1944 Tetsugaku ronbun shū dai yon hoi (Fourth supplement to the philosophical article) in NKZ XII: 397-425. Engl. transl.: "On the National Polity” in D. A. Dilworth, V.H. Viglielmo and Augustin Jacinto Zavala (eds) Sourcebook for Modern Japanese Philosophy (1998, Greenwood, Westport), 78-95.

45. Nishitani K, 1991 Nishida Kitarō (University of California Press, Berkley).

46. Nussbaum M, 1996 "Patriotism and Cosmopolitanism" Cohen J (ed.) For Love of Country: Debating the Limits of Patriotism (Beacon Press, Boston).

47. Panarin A.S., 1992, "Return to Civilization or 'Formal Isolation'?" in Russian Studies in Philosophy 31(2).

48. Pipes R, 1980 Struve. Liberal on the Left, 1870-1905 (Harvard University Press, Cambridge, MA).

49. Riasanovsky N, 1952 Russia and the West in the Teachings of the Slavophiles: A Study of Romantic Ideology (Harvard University Press, Cambridge).

50. Riasanovsky N, 1955 "Khomiakov on sobornost"' in Simmons E (ed.) Continuity and Change in Russian and Soviet Thought (Harvard University Press, Cambridge).

51. Riasanovsky N, 1972, "Asia Through Russian Eyes" in Vucinich W (ed.), Russia and Asia: Essays on the Influence of Russia on the Asian Peoples, 9.

52. Riasanovsky N, 1972, "Asia through Russian Eyes" in Wayne S. Vucinich (ed.): Russia and Asia: Essays on the Influence of Russia on the Asian Peoples (Stanford University Press, Stanford). 
53. Savitzky P, 1922, “Step' I osedlost”" [Steppe and sedentariness] in Novirkovka \& Sisemskaja, Rossia mezhdu Evropoj I Asiej: Evrazijskij soblazn. Antologia (Moscow: Nauka, 1993).

54. Savitzky P, 1925, "Evrasijstvo" in Evrazijskij vremennik 4 (Berlin).

55. Savitzky P, 1927 Geograficeskij obzor, 27.

56. Savitzky P, 1927 Rossija - osobyj geograficheskij mir [Russia - a particular geographical world] (Prag 1927).

57. Savitzky P, 1995 Kontinent Evrasia (Agraf, Moscow).

58. Schelting A von, 1948, Russland und Europa im russischen Geschichtsdenken (Francke, Bern).

59. Seton-Watson H, 1961 "Russia and Modernization" in Slavic Review 20(4).

60. Sil R, 2002 Managing "Modernity”: Work, Community and Authenticity in Late-Industrializing Japan and Russia (University of Michigan Press, Ann Arbor).

61. Tönnies F, 1886 Gemeinschaft und Gesellschaft (Fuess, Leipzig).

62. Torbakov I, 2003 "From the Other Shore: Some Reflections of Russian Émigré Thinkers on Soviet Nationality Policies 1920s-1930s" in Slavic \& East European Information Resources 4(4).

63. Vladimir Weidlé, 1976, "Russia and the West" [1956] in Schmemann (ed.) Ultimate Questions: An Anthology of Modern Russian Religious Thought (St. Vladimir's Seminar Press, Crestwood).

64. Walicki A, 1975, The Slavophile Controversy: History of a Conservative Utopia in NineteenthCentury Russian Thought (Clarendon Press, Oxford).

65. Watsuji T, 1937, Ningen no gaku toshite no rinrigaku (The significance of ethics for humanities). Watsuji Tetsurō Collected Works (WTZ) Vol. 9: 1-192 (Tokyo: Iwanami). Engl. transl.: Watsuji Tetsuro's Rinrigaku (SUNY Press, New York 1996).

66. Weinmayr E, 2005 “Thinking in Transition: Nishida Kitaro and Martin Heidegger” Philosophy East and West, 55(2).

67. Wiederkehr S, 2000, "Der Eurasianismus als Erbe N. Ja. Danilevskijs? Bemerkungen zu einem Topos der Forschung" Studies in East European Thought 52.

68. Zenkovsky V, 1995 History of Russian Philosophy Vol. 2 (Routledge and Kegan Paul, London). 


\title{
в России и Японии: \\ сравнение философии Нисиды Китаро \\ и Семёна Франка
}

Философские концепции культурного пространства

\author{
Т. Ботц-Борнштайн \\ Университет стран Персидского залива \\ по науке и технике, \\ Кувейт, 32093 Хавалли, п/я 7207
}

\begin{abstract}
Жан-Люк Нанси отмечает, что общество, не являясь абсолютным субъектом (я, воля, дух), по своей природе не вписывается ни в какую логическую метафизику. Несмотря на это или по причине этого, западная философия настоятельно пыталась интерпретировать общество исключительно при помощи этих метафизических терминов (Nancy, 1986, page 18, La Commonaute" de" soevre"e, Christian Bourgeois, Paris).

Некоторые размышления о российских и японских понятиях об обществе и пространстве показывают, что характеристики, данные Нанси и Кантом, типичны только для тех обществ, которые функционируют в рамках западной интеллектуальной концепции. Мне хотелось бы сравнить позиции Нисиды Китаро (1870-1935) и Семёна Л. Франка (1877-1950), которые разработали понятия «басё» и «соборность» в качестве альтернативных концепичий пространства. Как Нисида, так и Франк пытались преодолеть то, что они считали «типичным западным представлением об отдельных «я» как материальных «объектах». Такие процессы, как интуиция, являются неэффективными, потому что они лишь трансформируют в объект то, что им является по мнению «я». Для евразианиста организаџия государства сконцентрирована вокруг персонального Бога, а «симфоническая индивидуальность» РоссииЕвразии представлена неэгоистичным, общим сознанием.
\end{abstract}

Ключевые слова: Нисида Китаро, Семен Франк, Басё, соборность, философия космизма, сравнение русской и японской философии. 